\title{
Hubungan Tingkat Pengetahuan dan Sikap terhadap Kebiasaan Konsumsi Jamu pada Mayarakat Magelang Tahun 2019
}

\section{The Relationship of Knowledge and Attitude on Behavior Jamu Consumption in The Community of Magelang City in 2019}

\author{
Tiara Mega Kusuma ${ }^{1,2 *}$, Endaryanti Wulandari', Taufik Widiyanto ${ }^{1}$, Diah Kartika ${ }^{3}$ \\ ${ }^{1}$ Program Studi Farmasi, Fakultas Ilmu Kesehatan, Universitas Muhammadiyah Magelang, JL. Mayjend \\ Bambang Soegeng Km 5, Magelang, Indonesia \\ ${ }^{2}$ Pengurus Cabang Ikatan Apoteker Indonesia, Kabupaten Magelang, Indonesia \\ ${ }^{3}$ Mahasiswa Sarjana Farmasi, Fakultas Ilmu Kesehatan, Universitas Muhammadiyah Magelang, JL. Mayjend \\ Bambang Soegeng Km 5, Magelang, Indonesia \\ *E-mail: tiaramega@ummgl.ac.id
}

Received: 8 Mei 2020; Accepted: 1 Juli 2020; Published: 7 Juli 2020

\begin{abstract}
Abstrak
Jamu merupakan warisan budaya Indonesia yang perlu dilestarikan. Jamu tergolong dalam obat tradisional yang banyak digunakan masyarakat sebagai alternatif pengobatan, khususnya kota Magelang yang dikenal sebagai kampung jamu. Penelitian ini bertujuan untuk melihat hubungan tingkat pengetahuan dan sikap terhadap kebiasaan konsumsi jamu pada masyarakat kota dan kabupaten Magelang. Penelitian ini termasuk dalam penelitian dekriptif kuantitatif dengan pendekatan cross sectional dengan teknik pengambilan sampel secara acak. Data diperoleh dengan cara survei melalui penyebaran kuesioner dan dianalisis menggunakan uji chi-square $\left(X^{2}\right)$ untuk melihat masing-masing pengaruh tingkat pengetahuan atau sikap terhadap kebiasaan konsumsi jamu berdasarkan $p$-value, serta uji regresi logistik untuk melihat OR (Odds Ratio). Tingkat pengetahuan dan sikap tentang jamu memberikan pengaruh signifikan terhadap kebiasaan konsumsi jamu dengan $p$-value 0,003 dan $0,000(<0,005)$. Sikap terbukti mempunyai peluang paling tinggi untuk meningkatkan kebiasaan konsumsi jamu secara rutin $(23,262 x)$ dibandingkan tingkat pengetahuan $(1,273 x)$.
\end{abstract}

Kata Kunci: jamu, magelang, pengetahuan, sikap, kebiasaan konsumsi

\begin{abstract}
Jamu is a cultural heritage of Indonesia that needs to be preserved. Jamu is classified as traditional medicine which is widely used by the community as an alternative treatment, especially Magelang city's. This study aims to show relationship between the level of knowledge and attitudes towards the consumption habits of jamu in the community of Magelang. This research is included in a quantitative descriptive study with cross sectional approach with random sampling techniques. Data were obtained by surveying through the distribution of questionnaires and analyzed using the chi-square test (X2) to see each effect of the level of knowledge or attitudes towards herbal consumption habits based on p-value, and logistic regression tests to see the OR (Odds Ratio). The level of knowledge and attitudes about herbal medicine has a significant influence on the consumption habits of herbs with p-values of 0.003 and 0,000 $(<0.005)$. Attitude is proven to have the highest chance to improve the consumption habits of routine herbal medicine $(23,262 x)$ compared to the level of knowledge $(1,273 x)$.
\end{abstract}

Keywords:jamu, magelang, knowledge, attitude, behavior consumption

\section{PENDAHULUAN}

Jamu merupakan warisan budaya Indonesia yang digunakan masyarakat untuk menjaga kesehatan atau membantu penyembuhan penyakit, dan termasuk dalam golongan obat tradisional (Aditama, 2014). Jamu adalah bahan atauramuan bahan yang berasal dari tanaman, hewan, mineral, sediaan serian, atau campuran bahan tersebut yang secara turun menurun telah digunakan untuk pengobatan berdasarkan pengalaman dan diterapkan sesuai norma yang berlaku di masyarakat (Peraturan Menteri Kesehatan Republik Indonesia Nomor 6, 2016). 
Sampai saat ini, kebiasaan konsumsi jamu masih dilestarikan karena diyakini aman, tidak menimbulkan efek samping yang serius bila dibandingkan dengan obat kimia (Harmanto and Subroto, 2007). Pada tahun 2010, dilaporkan bahwa penduduk Indonesia yang pernah mengkonsumsi jamu lebih dari $50 \%$. Sebesar $95,60 \%$ penduduk Indonesia yang mengkonsumsi jamu merasakan adanya manfaat terhadap tubuh (Badan Penelitian dan Pengembangan Kesehatan, 2010). Tiga terbesar jenis jamu yang banyak digunakan adalah jahe $(50,36 \%)$, kencur $(48,77 \%)$, dan temulawak $(39,65 \%)$ yang digunakan dalam bentuk cairan ramuan jadi $(48,0 \%)$ (Badan Penelitian dan Pengembangan Kesehatan, 2018).

Namun demikian, keberadaan dan kebiasaan konsumsi jamu di Indonesia juga mengalami pasang surut (Purwaningsih, 2013). Brand image kalangan muda tentang jamu sebagai minuman pahit dan kuno (Tamara and Setyanto, 2018) yang ditujukan untuk orang tua membuat jamu semakin ditinggalkan (Yusa, 2016). Sedangkan pada kalangan dewasa disebabkan beberapa faktor seperti efektivitas jamu lebih lama dibandingkan obat kimia, isu maraknya penambahan BKO (Bahan Kimia Obat) dalam jamu dan efek negatif penggunaan jamu pada organ tubuh. Beberapa faktor tersebut menyebabkan penurunan kepercayaan dan minat konsumsi jamu oleh masyarakat di Indonesia (Harmanto and Subroto, 2007).

Opini tersebut muncul dapat disebabkan karena beberapa hal seperti tingkat pengetahuan dan sikap terhadap konsumsi jamu yang masih rendah. Pengetahuan dan sikap merupakan salah dua variabel yang dapat saling berinteraksi mempengaruhi perilaku individu dan kemudian berinteraksi dengan faktor-faktor lain seperti latar belakang pendidikan, pendapatan, dan pengalaman menggunakan obat tradisional.

Seperti halnya efek samping yang timbul dari jamu diakibatkan oleh ketidaktahuan masyarakat tentang aturan dan cara pakai jamu yang baik, seperti takaran dosis dan interaksinya dengan obat kimia. Selain itu, ketidaktahuan masyarakat tentang khasiat jamu yang tidak timbul secara instan seperti hal nya obat kimia. Efek "Cespleng" justru mengindikasikan jamu ditambahkan BKO (Sidoretno and Rz, 2018).

Berdasarkan pendekatan permasalahan di atas, serta mengingat belum banyaknya penelitian yang serupa, menarik minat peneliti untuk menganalisis faktor-faktor yang berpengaruh terhadap kebiasaan konsumsi jamu di Kabupaten dan Kota Magelang.

\section{METODE PENELITIAN Desain Penelitian}

Penelitian ini termasuk dalam metode kuantitatif bersifat observasional dengan pendekatan cross sectional menggunakan 200 responden di Kabupaten dan Kota Magelang pada berbagai variabel demografi (jenis kelamin, usia, tingkat pendidikan, pendapatan, dan pengalaman menggunakan jamu) pada tahun 2019.

\section{Variabel Penelitian}

Variabel bebas yang digunakan dalam penelitian ini adalah pengetahuan dan sikap. Sedangkan variabel terikatnya adalah kebiasaan konsumsi jamu secara rutin.

\section{Definisi Operasional}

1. Pengetahuan adalah pemahaman umum responden tentang jamu, seperti penggunaan, isi/ kandungan, efek samping, dan tingkat keamanan.

2. Sikap adalah tanggapan responden terhadap penerimaan jamu untuk pengobatan atau pemeliharaan kesehatan untuk diri sendiri dan orang lain.

3. Kebiasaan konsumsi jamu secara rutin adalah tindakan yang dilakukan responden untuk konsumsi jamu racikan selama 2 minggu terakhir.

4. Jamu racikan adalah jamu yang dibuat dengan cara merebus bagian tanaman obat baik berupa bahan segar maupun simplisia.

\section{Teknik Pengumpulan Data}


Data dikumpulkan dengan metode survei melalui penyebaran lembar kuesioner yang sebelumnya telah dilakukan uji validitas dan reliabilitas kepada responden, meliputi demografi responden, pengetahuan, sikap, dan kebiasaan konsumsi jamu. Kategori tiap variable dapat dilihat pada Tabel 1.

Tabel 1. Kategori tiap variabel

\begin{tabular}{lll}
\hline Variabel & Coding & Kriteria \\
\hline Pengetahuan & Baik & $\geq 70 \%$ \\
& Tidak baik & $<70 \%$ \\
Sikap & Positif & $\geq$ rata-rata \\
& Negatif & $<$ rata-rata \\
Kebiasaan & Ya & $\leq 2$ minggu \\
konsumsi & Tidak & $>2$ minggu \\
\hline
\end{tabular}

Kategori tiap tabel berdasarkan rancangan penelitian yang dilakukan oleh (Febriyanto, 2016) yang membagi kriteria dalam skala rasio untuk pengetahuan, skala ordinal untuk sikap, dan skala rasio untuk perilaku konsumsi.

\section{Analisis Data}

Pada penelitian ini, data dianalisa menggunakan uji chi-square $\left(X^{2}\right)$ dengan program SPSS untuk melihat masing-masing pengaruh tingkat pengetahuan atau sikap terhadap kebiasaan konsumsi jamu, serta uji regresi logistik untuk melihat OR (Odds Ratio) atau faktor resiko antara variabel bebas dan terikat (Febriyanto, 2016; Swarjana, 2016).

\section{HASIL DAN PEMBAHASAN}

Penelitian tentang kebiasaan konsumsi jamu secara rutin dalam kurun waktu $\leq 2$ minggu di Magelang belum pernah dilakukan. Magelang merupakan salah satu kota yang sampai saat ini banyak daerahnya dikenal sebagai kampung jamu karena sebagian besar penduduknya memproduksi dan menjual jamu racikan. Eksistensi penjual jamu mengindikasikan bahwa tingkat konsumsi jamu di Magelang yang masih tinggi. Namun hal tersebut belum bisa dipastikan jika belum pernah dilakukan penelitian tentang kebiasaan konsumsi jamu secara rutin di Magelang.

Perilaku kebiasaan konsumsi jamu dipengaruhi oleh banyak faktor, baik yang bersifat langsung, seperti pengetahuan dan sikap, serta bersifat tidak langsung yang dipengaruhi oleh faktor intern dan ekstern masyarakat.

Eksistensi jamu sebagai obat tradisional sempat mengalami pasang surut, dimana banyak informasi yang kurang tepat terhadap jamu akibat ketidaktahuan masyarakat. Hal tersebut dimungkinkan berpengaruh pada tingkat konsumsi jamu.

Faktor-faktor lain yang mungkin berpengaruh secara tidak langsung pada kebiasaan jamu adalah faktor intern dan lingkungan seperti umur, latar belakang pendidikan, dan pendapatan (Tabel 2.). Faktor tersebut juga mempengaruhi pengetahuan dan sikap responden.

Tabel 2. Demografi responden

\begin{tabular}{llcc}
\hline $\begin{array}{l}\text { Faktor- } \\
\text { faktor }\end{array}$ & Keterangan & Jumlah & Persen \\
\hline Jenis kelamin & Laki-laki & 88 & 44 \\
& Perempuan & 112 & 56 \\
Umur & $20-39$ & 86 & 43 \\
& $40-59$ & 103 & 51 \\
& $\geq 60$ & 11 & 5 \\
Latar & SMP & 29 & 14,5 \\
belakang & SMA & 91 & 45,5 \\
pendidikan & D3/S1/S2 & 80 & 40,0 \\
Pendapatan & $<2$ juta & 101 & 50,5 \\
& $2-4$ juta & 92 & 46,0 \\
& $>4$ juta & 7 & 3,5 \\
Pengalaman & Membaik & 42 & 21 \\
minum jamu & Sama saja & 106 & 53 \\
& Memburuk & 52 & 26 \\
\hline
\end{tabular}

Berdasarkan data demografi responden pada Tabel 2, menunjukkan bahwa konsumen jamu terbesar adalah perempuan dengan rentang umur 40-59 tahun, latar belakang pendidikan SMA, pendapatan $<2$ juta. Sebagian besar responden menyatakan jamu tidak memperbaiki ataupun memperburuk keadaan, artinya tidak memberikan efek apapun di dalam tubuh.

Pengalaman minum jamu ini memungkinkan berpengaruh pada kebiasaan 
konsumsi jamu, dimana lebih dari 50\% masyarakat Magelang yang pernah mengkonsumsi jamu nyatanya tidak mengkonsumsi jamu secara rutin.

Perilaku merupakan suatu tindakan yang dapat dipengaruhi oleh hasil dari sikap dan pengetahuan yang dimiliki. Menurut Teori Bloom, perilaku manusia secara umum terbagi menjadi 3 domain, yaitu pengetahuan (kognitif), sikap (afektif), dan tindakan (psikomotor) yang saling memiliki keterkaitan. Sehingga pengetahuan dan sikap termasuk dalam faktor yang berhubugan langsung dengan perilaku kebiasaan konsumsi jamu.

Hasil pengetahuan dan sikap masyarakat Magelang terhadap perilaku kebiasaan konsumsi jamu dapat diketahui dengan penyebaran lembar kuesioner maupun wawancara untuk mendapatkan data yang lebih komprehensif. Lembar kuesioner yang digunakan oleh penulis sebelumnya telah dilakukan uji validasi untuk menunjukkan bahwa kuesioner dapat menghasilkan pengukuran yang tepat dan akurat sesuai dengan tujuan test, serta uji reliabilitas untuk menunjukkan derajat stabilitas, konsistensi, daya prediksi dan akurasi, seperti terlihat pada Tabel 3 dan 4. (Matondang, 2009).

Tabel 3. Hasil Uji Validitas dan Reliabilitas Kuesioner Tingkat Pengetahuan

\begin{tabular}{|c|c|c|c|}
\hline No Soal & $\mathbf{r}$ hitung & $r$ tabel & keterangan \\
\hline 1 & 0,905 & 0,676 & valid \\
\hline 2 & 0,923 & 0,676 & valid \\
\hline 3 & 0,942 & 0,676 & valid \\
\hline 4 & 0,916 & 0,676 & valid \\
\hline 5 & 0,921 & 0,676 & valid \\
\hline \multicolumn{3}{|c|}{ Crossbach's alpha } & 0,872 \\
\hline
\end{tabular}

Uji signifikan 0,05

Tabel 4. Hasil Uji Validitas dan Reliabilitas Kuesioner Tingkat Penerimaan atau Sikap

\begin{tabular}{cccc}
\hline No Soal & r hitung & r tabel & keterangan \\
\hline 1 & 0,911 & 0,595 & valid \\
2 & 0,957 & 0,595 & valid \\
3 & 0,932 & 0,595 & valid \\
4 & 0,964 & 0,595 & valid \\
5 & 0,905 & 0,595 & valid \\
\hline \multicolumn{4}{c}{ Crossbach's alpha } \\
\hline
\end{tabular}

Uji signifikan 0,05
Berdasarkan Tabel 3 dan tabel 4 diketahui bahwa uji validitas dan reliabilitas terhadap pengetahuan dan sikap memiliki $\mathrm{r}$ hitung > $\mathrm{r}$ tabel dan crossbach's alpha > 0,700 sehingga semua soal yang diberikan oleh peneliti dikatakan telah valid dan reliabel.

Menurut Notoatmodjo (2003), sikap merupakan reaksi atau respon seseorang yang masih tertutup terhadap suatu stimulus atau objek. Sikap belum merupakan suatu tindakan, akan tetapi merupakan predisposisi tindakan suatu perilaku, sehingga memungkinkan sebuah sikap positif tidak terwujud dalam tindakan nyata(Soekidjo, 2003). Sikap akan diikuti atau tidak diikuti oleh tindakan mengacu kepada pengalaman. Faktor pengalaman minum mungkin mempengaruhi tindakan untuk mengkonsumsi jamu untuk kesehatan. Hal ini terbukti pada sebanyak $43 \%$ responden yang menyatakan sikap positif pada penerimaan jamu ternyata tidak mengkonsumsi jamu secara rutin.

Tabel 5 dan 6 menunjukkan bahwa pengetahuan maupun sikap responden terhadap jamu memiliki p-value 0,003 dan $0,000(<0,05)$.

Tabel 5. Hubungan pengetahuan responden dengan kebiasaan konsumsi jamu

\begin{tabular}{lccc}
\hline $\begin{array}{l}\text { Variabel } \\
\text { bebas }\end{array}$ & \multicolumn{2}{c}{ Kebiasaan Konsumsi } & \multirow{2}{*}{ Ya } \\
\hline $\begin{array}{l}\text { Pengetahuan } \\
\text { Baik }\end{array}$ & $60(50 \%)$ & $60(50 \%)$ & 0,003 \\
$\quad$ Tidak Baik & $23(29 \%)$ & $57(71 \%)$ & \\
\hline *) $X^{2}$ test & & &
\end{tabular}

Tabel 6. Hubungan sikap responden dengan kebiasaan konsumsi jamu

\begin{tabular}{lccc}
\hline $\begin{array}{l}\text { Variabel } \\
\text { bebas }\end{array}$ & \multicolumn{2}{c}{ Kebiasaan Konsumsi } \\
Ya & Tidak & p* \\
\hline $\begin{array}{l}\text { Sikap } \\
\text { Positif }\end{array}$ & $80(57 \%)$ & $60(43 \%)$ & 0,000 \\
Negatif & $3(5 \%)$ & $57(95 \%)$ & \\
*) $X^{2}$ test & & &
\end{tabular}

Hal tersebut berarti pengetahuan dan sikap memberikan pengaruh signifikan terhadap kebiasaan konsumsi jamu.Kebiasaan 
konsumsi jamu dapat dikaitkan dengan kepercayaan tradisi minum jamu untuk kesehatan yang sudah diterima luas oleh masyarakat dan telah menjadi sebuah warisan budaya tak benda (WBTb) Jawa Tengah.

Faktor resiko sikap dan pengetahuan terhadap kebiasaan konsumsi jamu dapat dilihat dari odds ratio (OR). Odds ratio lebih dari 1 memiliki kemungkinan yang lebih tinggi daripada nilai < 1 (Tabel 7).

Tabel 7. Hasil uji regresi logistik antara pengetahuan dan sikap terhadap kebiasaan konsumsi jamu

\begin{tabular}{lcccc}
\hline \multirow{2}{*}{ Variabel } & \multirow{2}{*}{ OR } & \multicolumn{2}{c}{$\mathbf{9 5 \%} \mathbf{C l}$} & \multirow{2}{*}{$\mathbf{p}$} \\
\cline { 3 - 4 } & & Lower & Upper & \\
\hline Pengetahuan & 1,273 & 0,629 & 2,576 & 0,502 \\
Sikap & 23,262 & 6,797 & 79,612 & 0,000 \\
\hline
\end{tabular}

Berdasarkan Tabel 7, variabel sikap terbukti mempunyai peluang paling tinggi untuk meningkatkan kebiasaan konsumsi jamu secara rutin dibandingkan variabel pengetahuan. Nilai OR (Odds Ratio) 23,62 pada variabel sikap mempunyai arti bahwa sikap positif responden terhadap penerimaan jamu memberikan kebiasaan minum jamu 23,62x lebih besar dibandingkan responden yang bersikap negatif.

\section{KESIMPULAN}

Kebiasaan konsumsi jamu secara rutin oleh masyarakat Magelang dipengaruhi oleh tingkat pengetahuan dan sikap penerimaan jamu. Sikap mempunyai peluang paling tinggi untuk meningkatkan kebiasaan konsumsi jamu secara rutin dibandingkan tingkat pengetahuan.

\section{Daftar Pustaka}

Aditama, T. Y. 2014. Jamu dan Kesehatan. Jakarta: Badan Penelitian dan Pengembangan Kesehatan.

Badan Penelitian dan Pengembangan Kesehatan. 2010. Laporan Riset Kesehatan Dasar Nasional 2010. Jakarta: Lembaga Penerbit Badan Penelitian dan Pengembangan Kesehatan . LPB..

Badan Penelitian dan Pengembangan Kesehatan. 2018. Laporan Riset Kesehatan Dasar Nasional 2018. Jakata: Lembaga Penerbit Badan Penelitian dan Pengembangan Kesehatan . LPB..

Febriyanto, M. A. B. . 2016. Hubungan Antara Pengetahuan dan Sikap Dengan Perilaku Konsumsi Jajanan Sehat Di MI Sulaimaniyah Mojoagung Jombang, http://repository.unair.ac.id/46023/2/FKM.\%20290-16\%20Feb\%20h.pdf. Universitas Airlangga. doi: 10.5151/cidi2017-060.

Harmanto, N. and Subroto, M. A. 2007. Pilihlah Jamu dan Herbal Tanpa Efek Samping. Jakarta: PT Elex Media Komputindo.

Matondang, Z. 2009. 'Validitas dan Reliabilitas Suatu Instrumen Penelitian', Jurnal Tabularasa PPS UNIMED, 6. 1.. doi: 10.4028/www.scientific.net/AMM.496-500.1510.

Peraturan Menteri Kesehatan Republik Indonesia Nomor 6. 2016. 'Tentang Formularium Obat Herbal Asli Indonesia'. Jakarta: Direktorat Jenderal Peraturan Perundang-Undangan Kementerian Hukum dan Hak Asasi Manusia Republik Indonesia, Jakarta.

Purwaningsih, E. H. 2013. 'Jamu, Obat Tradisional Asli Indonesia Pasang Surut Pemanfaatannya di Indonesia', Jamu, Obat Tradisional, 1. 2..

Sidoretno, W. M. and Rz, I. O. 2018. 'Edukasi Bahaya Bahan Kimia Obat Yang Terdapat 
Didalam Obat Tradisional', Jurnal Pengabdian Masyarakat, 1. 2., pp. 36-42.

Soekidjo, N. 2003. Ilmu Kesehatan Masyarakat: Prinsip-Prinsip Dasar. Jakarta: PT Rineka Cipta.

Swarjana, I. K. 2016. Statistika Kesehatan. Jakarta: CV Andi Offset.

Tamara, J. and Setyanto, Y. 2018. 'Strategi Public Relations dalam Membangun Brand Image Jamu . Studi pada Suwe Ora Jamu Kedai Jamu \& Kopi .’, Prologia, 2. 2., pp. 377-384.

Yusa, I. M. M. 2016. 'Imagologi Mbok Jamu Sebagai Representasi Wanita Etnis Jawa Tradisional dalam Diskursus Stereotype Citra', Jurnal Studi Kultural, I. 1., pp. 1-6. 